\title{
Altered carbon cycling and trace- metal enrichment during the late Valanginian and early Hauterivian
}

\section{Journal Article}

\section{Author(s):}

Kuhn, Oliver; Weissert, Helmut; Föllmi, Karl B.; Hennig, Susanne

Publication date:

2005-12

Permanent link:

https://doi.org/10.3929/ethz-b-000034953

\section{Rights / license:}

In Copyright - Non-Commercial Use Permitted

\section{Originally published in:}

Eclogae Geologicae Helvetiae 98(3), https://doi.org/10.1007/s00015-005-1172-7 


\title{
Altered carbon cycling and trace-metal enrichment during the late Valanginian and early Hauterivian
}

\author{
Oliver Kuhn $^{1}$, Helmut Weissert ${ }^{2}$, Karl B. Föllmi ${ }^{3} \&$ Susanne Hennig $^{2}$
}

Key words: Manganese, iron, stable carbon isotopes, early Cretaceous, metal enrichment, paleoceanography

\begin{abstract}
Carbonates of Valanginian age deposited in the Tethys and Atlantic Oceans show a distinct positive $\delta^{13} \mathrm{C}$ excursion $\left(\Delta \delta^{13} \mathrm{C}=1.5 \%{ }^{-}-2 \%\right)$ in sections of the neritic, hemipelagic, and pelagic environment. This excursion records a major climate-induced perturbation of the global carbon system. The $\delta^{13} \mathrm{C}$ excursion is accompanied by enrichments in manganese $(\mathrm{Mn})$ and iron $(\mathrm{Fe})$. The correlation of the $\delta^{13} \mathrm{C}$ excursion with trends in $\mathrm{Mn}$ and $\mathrm{Fe}$ contents reflects changes in Valanginian paleoceanography and climate. Fe enrichment occurs mainly in terrestrial, platform, and shelf regions. In a basinal direction the Fe content decreases, whereas the $\mathrm{Mn} / \mathrm{Fe}$ ratio increases. An increase in sedimentary $\mathrm{Mn}$ and $\mathrm{Fe}$ concentrations is related to elevated continental weathering rates and to widespread dys- or anoxia that favored metal deposition in Valanginian sediments. Various oceanographic changes (e.g., expansion of oxygen-minimum zones) resulting from increased continental runoff led to a strong remobilization and focused reprecipitation of metals in the oceans of the Valanginian stage.
\end{abstract}

\section{Introduction}

The evolution of the global carbon cycle through Earth history is documented by the inorganic and organic carbon isotope record of marine and terrestrial sediments. Major changes in carbon cycling leave a positive or negative carbon isotope anomaly in the isotope record (e.g., Hayes et al. 1999). High amplitude perturbations $(\Delta>1 \%$ ) of the carbon cycle exceeding the residence time of carbon in the ocean (presently at approx-

\section{ZUSAMMENFASSUNG}

Karbonate des Valanginian aus den Tethys- und Atlantik-Räumen weisen in neritischen, hemipelagischen und pelagischen Abfolgen eine markante, positive $\delta^{13} \mathrm{C}$-Exkursion $\left(\Delta \delta^{13} \mathrm{C}=1.5 \%\right.$ - $2 \%$ o $)$ auf. Diese Exkursion wird auf eine grossräumige Änderung im globalen Kohlenstoff-Budget zurückgeführt, welcher mit einem Klimawechsel in Zusammenhang steht. Die $\delta^{13} \mathrm{C}$-Exkursion wird von Anreicherungen in Mangan ( $\mathrm{Mn})$ und Eisen $(\mathrm{Fe})$ begleitet. Die Korrelation der $\delta^{13} \mathrm{C}$-Exkursion mit den stratigraphischen Tendenzen in sedimentären $\mathrm{Mn}$ - und Fe-Konzentrationen weist auf Änderungen in der Paläozeanographie und im Klima des Valanginian hin. Die Zunahme in den Mn- und FeKonzentrationen hängt mit erhöhten Verwitterungsraten auf dem Kontinent und mit weitverbreiteten dysoxischen bis anoxischen Bedingungen in den Ozeanen zusammen, welche die erhöhte Metallablagerung in Sedimenten des Valanginian ermöglichte. Fe-Anreicherungen fanden vorwiegend in den terrestrischen und flachmarinen Bereichen statt. In Richtung des Beckenbereiches nimmt der Fe-Gehalt ab und das Verhältnis $\mathrm{Mn} / \mathrm{Fe}$ zu. Die Metallanreicherung während des Valanginian wurde von einer Änderung im Wasserkreislauf, Verwitterung und Erosion in Zusammenhang mit einer wichtigen Zunahme des Treibhauseffektes verursacht. Als direkte Folge der intensivierten Verwitterung wurde die Freisetzung der Metalle beschleunigt und die Verfrachtung der Metalle in die Ozeane nahm zu. Verschiedene Wechsel in den ozeanographischen Bedingungen wie die Ausdehnung der SauerstoffMinimumzonen führten zu einer starken Remobilisation und fokussierten Ablagerung der Metalle in den Ozeanen des Valanginian.

\footnotetext{
${ }^{1}$ Shell China Exploration and Production Co., 100004 Bejing, P.R. China. E-mail: kuhn-china@shell.com

${ }^{2}$ Geological Institute, ETH Zurich, 8092 Zurich, Switzerland. E-mail: helmi@erdw.ethz.ch, shennig@freesurf.ch

${ }^{3}$ Institut de Géologie, Université de Neuchâtel, 2007 Neuchâtel, Switzerland. E-mail: karl.foellmi@unine.ch
}

imately 100ky; Kump \& Arthur 1999) were coupled with a reorganization of global climate, with changes in oceanography, and with evolutionary steps in marine and terrestrial biota (e.g., Arthur et al. 1985). These coupled changes of climate, oceans and biosphere contributed to a renewed stabilization of carbon cycling and of the global climate up to million years after the incipient disturbance of the C-cycle (e.g., Weissert 1989). 


\section{the oceanic manganese cycle}

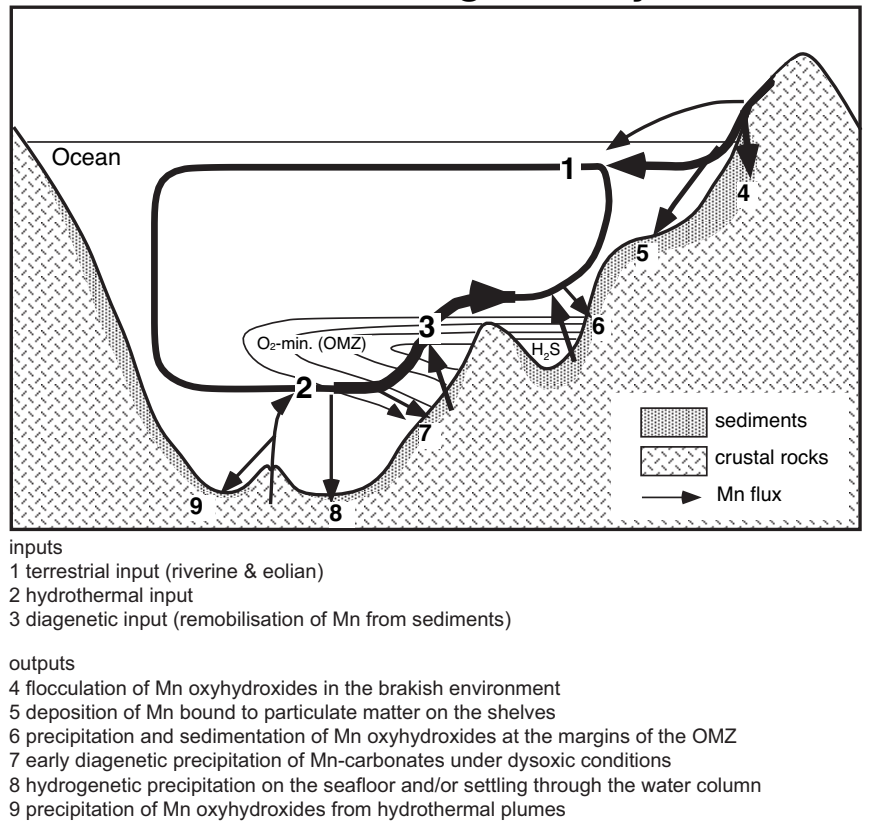

Fig. 1. Model of the oceanic Mn cycle with information on input and output processes and locations of $\mathrm{Mn}$ burial. Compare text for references.

The $\delta^{13} \mathrm{C}$ record of the oceans varies in response to the cycling of carbon between the oceans and other reservoirs. Changes in partitioning of carbon between the oxidized and the reduced marine carbon sink best explain measured longterm changes ( $10^{4}$ to $10^{7}$ years) in the isotopic composition of inorganic and organic carbon (Hayes et al. 1999). Because of the large fractionation between organic and inorganic carbon reservoirs, these changes commonly are attributed to the burial and erosion of organic matter (e.g., Arthur et al. 1985). Variations in less fractionated fluxes, such as carbonate carbon, however, also contribute to isotope excursions (e.g., Weissert et al. 1998). Changes in carbon cycling recorded in Cisotope stratigraphy are coupled with major changes of climate and reorganization of oceanography.

The transition-metal content (e.g., Mn, Fe) in marine sediments provides information on changing weathering patterns and on the evolution of oceanography during a time of altered carbon cycling (Brumsack 1986; Arthur \& Dean 1992). Earlier studies have shown that marine manganese and iron ores were formed at times of peculiar paleoceanographic conditions. "Mn giants" of the early Toarcian, late Jurassic, Aptian, Albian, Cenomanian/Turonian boundary, and Miocene are correlated with ocean-wide anoxia (Oceanic Anoxic Events) and/or changes in the carbon cycle as expressed by positive $\delta^{13} \mathrm{C}$ excursions (e.g., Pomerol 1983; Frakes \& Bolton 1984, 1992; Schlanger et al. 1987; Van Houten \& Arthur 1989; Jenkyns et al. 1991, 2002; Pratt et al. 1991; Corbin et al. 2000; De Rafélis et al. 2001).
Most $\mathrm{Mn}$ and $\mathrm{Fe}$ entering the present-day oceanic reservoir are mobilized on the continent by physical weathering and erosion of rocks and by dissolution of metal-bearing minerals during biochemical weathering (Fig. 1). Bender et al. (1977) calculated the present-day total input of Mn into the ocean to be $6.3 \mu \mathrm{g} / \mathrm{cm}^{2} / \mathrm{yr}$. Most (95\%-97\%) of this input of Mn into the marine cycle stems from continental sources and is transferred to the ocean by fluviatile and eolian transport, mostly ( $>99 \%)$ as particulate matter. The oceanic hydrothermal flux of $\mathrm{Mn}$ accounts for less than $5 \%\left(\approx 0.2 \mu \mathrm{g} / \mathrm{cm}^{2} / \mathrm{yr}\right)$ of the total yearly $\mathrm{Mn}$ input, despite its high concentration in hydrothermal fluids (up to $10^{6}$ times the concentration in ocean water; Bender et al. 1977; Drever et al. 1988; Burton \& Statham 1988). The hydrothermal input leads to locally, perhaps regionally enriched (max. $1000 \mathrm{~km}$ from its source) $\mathrm{Mn}^{2+}$ concentrations in the deep-water layers in the form of Mn-rich hydrothermal plumes (Klinkhammer \& Hudson 1987). The Mn reflux into the marine cycle through remobilization of $\mathrm{Mn}$ in sediments is not quantified yet. Box model calculations suggest that this input is important, too (Landing \& Bruland 1980; Burton \& Statham 1988).

The concentration of Mn dissolved in ocean water, and in the form of suspended and deposited sediment is mainly controlled by redox cycling (Bender et al. 1977). Mn occurs in the ocean in the form of $\mathrm{Mn}^{2+}$ and $\mathrm{Mn}^{4+}$ ions. Under oxidizing conditions $\mathrm{Mn}^{4+}$ is precipitated as $\mathrm{MnOOH}$ or in the form of other Mn phases (e.g., Hem 1972). Under reducing conditions, manganese oxyhydroxides are dissolved and Mn occurs in an aqueous state as $\mathrm{Mn}^{2+}$ ions. The concentration of dissolved $\mathrm{Mn}$ in anoxic waters is up to 1000 times higher (max. $1000 \mathrm{ppb}$ ) than that in oxic environments (Martin \& Knauer 1983). For this reason, anoxic water bodies act as transport paths of $\mathrm{Mn}$ in the ocean. The most important sinks of dissolved Mn in the ocean are (1) adsorption onto sinking detrital and biogenic particles and (2) hydrogenous and hydrothermal precipitation of Mn oxyhydroxides either in the sediments or in the water column (Martin \& Knauer 1982, 1983; Burton \& Statham 1988). Generally the preservation potential of Mn oxyhydroxides in a sediment is low, due to their instability under reducing conditions. The majority of Mn oxyhydroxides that are distributed on today's ocean floor will redissolve during early diagenesis. Preservation and burial is controlled by the sedimentation rate and by the Mn-flux and burial rates of organic carbon that controls the rate of reductive dissolution of manganese in the sediment (Calvert \& Pedersen 1993). Reduced $\mathrm{Mn}$ is either released from the sediment and re-precipitated in the oxic part of the water column or it is incorporated into newly formed Mn-carbonates (Calvert et al. 1996).

The natural input of iron into the ocean involves (1) particulate transport from the continents in the form of suspended material in rivers or eolian dust, (2) "dissolved" input, that is the sum of dissolution, complexes, colloids and particles $<0.45$ $\mu \mathrm{m}$ and (3) hydrothermal input. The particulate transport accounts for more than $99 \%$ of the total Fe-input (ca. $7.5 \times 10^{8}$ $\mathrm{T} / \mathrm{y}$ ). The dissolved input is calculated to be in the range of 
Valanginian/ Hauterivian metal enrichments and

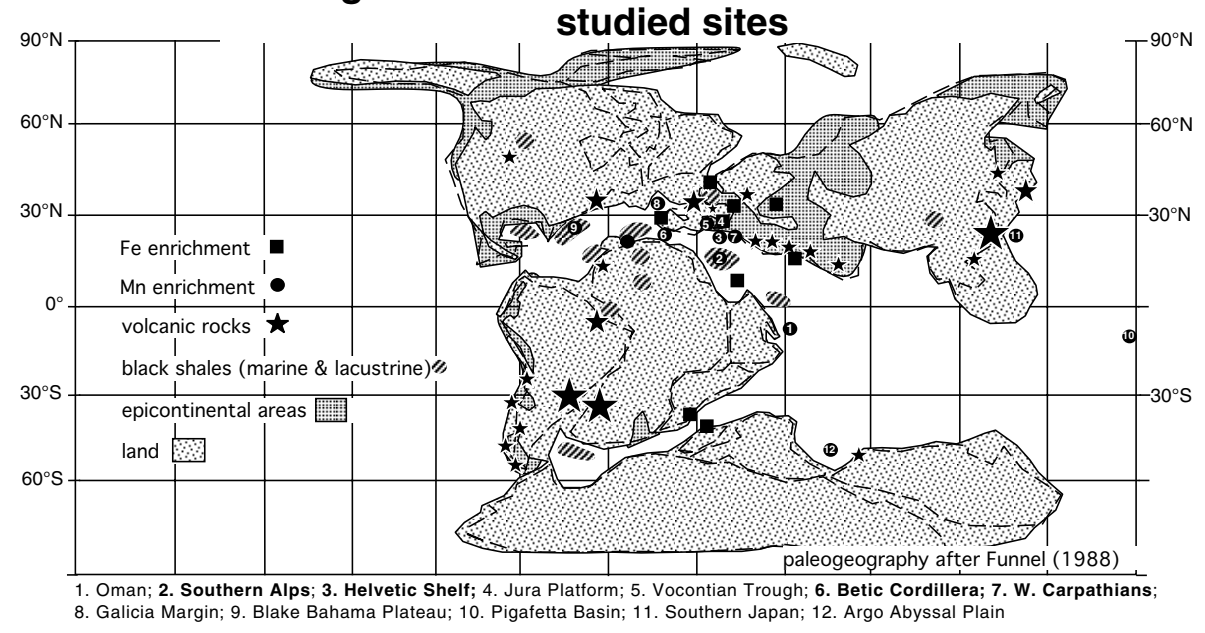

Fig. 2. Valanginian/Hauterivian paleogeography (after Funnel 1988) with the spatial distribution of Fe- and Mn enrichments, continental volcanic rocks and black shales. The location of sections discussed in the text is indicated by numbers and sections analysed in this study are shown by bold text.
$1.5 \times 10^{6} \mathrm{~T} / \mathrm{y}$ (Berner \& Berner 1987). Despite the fact that hydrothermal input of $\mathrm{Fe}$ through the leaching of basalts by hot fluids is rather high $\left(30 \times 10^{6} \mathrm{~T} / \mathrm{y}\right)$, it does not affect the oceanic Fe budget, owing to related removal of dissolved Fe by oxidation and precipitation of $\mathrm{Fe}$ minerals in the immediate neighborhood of hydrothermal sources (Wolery \& Sleep 1988). This explains why $\mathrm{Fe}$ does not form plumes in oxic bottom water.

Fe behaves similarly to $\mathrm{Mn}$ in the aqueous environment. Possible sinks of $\mathrm{Fe}$ in the ocean are (1) deposition of $\mathrm{Fe}$ bound to detrital material, which takes place preferentially in the neritic and hemipelagic part of the ocean; (2) deposition of Fe bound to eolian dust in the pelagic areas; (3) precipitation of $\mathrm{Fe}$ (hydro)oxides and $\mathrm{Fe}$ sulfides around centers of hydrothermal activity; (4) formation of authigenic iron minerals from geothermal brines; (5) formation of authigenic, Fe-rich clay minerals (e.g., glauconite, berthierine, vernadite) on the shelves in areas of low sedimentation; and (6) the formation of $\mathrm{Fe}$ sulfides in reducing sediments. The importance of each of the cited sinks may vary strongly in space and time because of their strong dependence on redox conditions and $\mathrm{Fe}$ source fluxes.

$\mathrm{Mn}$ and Fe strongly fractionate in the marine environment due to more rapid precipitation of oxidized iron and to efficient iron fixation in the sediment as sulfide under fully anoxic conditions (Force \& Cannon 1988). The precipitation of Mn as Mn carbonates (e.g., rhodochrosite) is limited to oxygen-poor but not fully anoxic environments. Because of the described fractionation processes, $\mathrm{Mn} / \mathrm{Fe}$ ratios of sediments increase with increasing distance from the continent from 0.02 to 0.2 to $>100$ in open marine settings (Seibold \& Berger 1993; Lisitzin 1996; Tab. 1).

In this study, we are interested in the response of oceans, climate, and the biosphere to a globally identified perturbation of the carbon cycle around 135 my ago. This perturbation is recorded in the C-isotope record of the Valanginian and it has been documented and accurately dated in pelagic successions from the Tethys, Atlantic, and Pacific Oceans (Lini et al. 1992; Channell et al. 1993; Erba et al. 2004). These studies have also confirmed that the carbon-isotope signature fixed in biogenic carbonate serves as an excellent stratigraphic tool and as a source of information in paleoceanography. Manganese (Mn) and iron $(\mathrm{Fe})$ are the two trace metals we used as paleoenvironmental indicators for this study. Mn is used as a proxy indicator of changing oceanography and oxygen contents in intermediate and deep waters. The Fe distribution, combined with the Mn occurrence, serves as an indicator of evolving weathering conditions during the identified anomaly in the carbon cycle.

For our investigation we selected sedimentary successions, which were deposited along a south-north transect through the Tethys Ocean from a deep pelagic environment to a shallow carbonate ramp setting (Fig. 2). The selection of this study area offers the opportunity to reconstruct coupled changes in shallow and deep-water oceanography at the time of the Valanginian C-isotope event. The variation in $\mathrm{Mn} / \mathrm{Fe}$-ratios within the studied segment of the Tethys Ocean also facilitates the search for the major source of metal input into the Tethys Ocean during the $\mathrm{C}$-isotope excursion.

\section{Analytical methods}

For this study, we analyzed the C-isotope composition of bulk carbonates. The samples were measured with a VG 903 and/or a Prism mass-spectrometer at the ETH Zurich. The isotopic composition of carbonate was determined by the analysis of $\mathrm{CO}_{2}$ evolved by reaction of ground bulk samples with $100 \%$ phosphoric acid at $50{ }^{\circ} \mathrm{C}(\mathrm{VG} 903)$ or $90{ }^{\circ} \mathrm{C}$ (Prism). Stable isotope data from the Capriolo section (Fig. 3) are taken from Lini (1994). The results are expressed in the $\delta$ notation relative to the VPDB-standard. 


\section{Section Capriolo: Southern Alps}

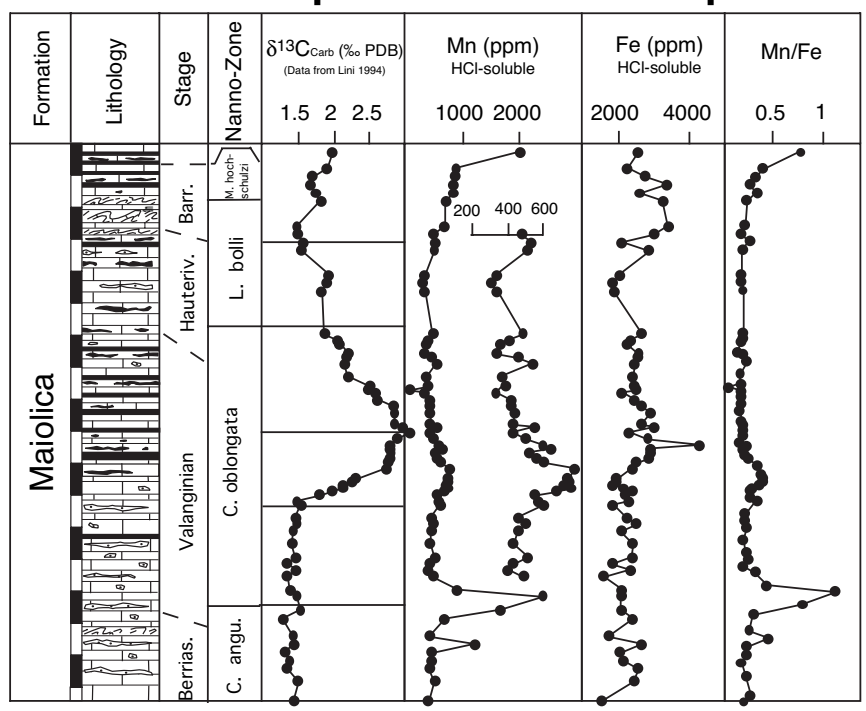

lithologic signatures:
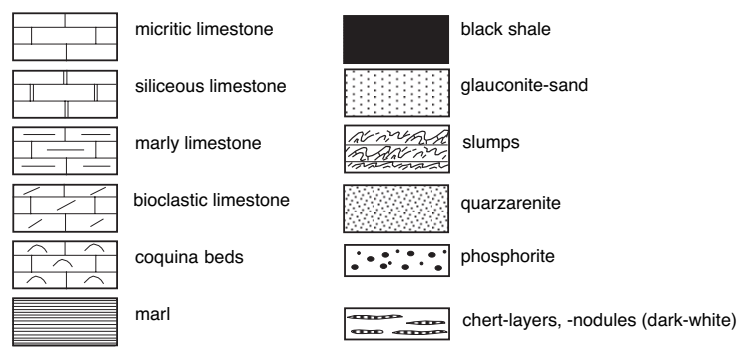

Fig. 3. Section Capriolo from the southern Tethys with lithologic succession, nannoplankton-zonation, $\delta^{13} \mathrm{C}$-curve, contents of $\mathrm{Mn}$ and $\mathrm{Fe}$ bound in the soluble fraction and Mn/Fe-ratios calculated from these values (after Kuhn 1996). The Mn-curve is shown as the complete dataset (left side of column) and as a subset with an expanded scale (right side).

For analysis of $\mathrm{Mn}$ and Fe content 20 to $50 \mathrm{mg}$ of sample were drilled from cleaned, fresh rock surfaces. The dried powder was weighed and immersed in $10 \% \mathrm{HCl}$ for $5 \mathrm{~h}$. This treatment dissolves carbonate minerals, Mn oxides, and hydroxides. The insoluble residue was isolated by centrifugation, dried at $50 \mathrm{C}^{\circ}$ and weighed. The $\mathrm{Mn}$ and Fe content in the soluble fraction was measured with a Perkin Elmer atomic absorption spectrometer (AAS 1100) with acetylene/air flame. The reproducibility of the measurements lies in the range of $+/-6 \%$. Dissolution experiments with sample material from the section Wellenberg SB2 (see below) showed that between 95\% and $100 \%$ of $\mathrm{Mn}$ is bound to the $\mathrm{HCl}$-soluble fraction. A detailed geochemical $\left(\mathrm{CaCO}_{3}, \mathrm{C}_{\text {org }}, \mathrm{XRF}\right)$ and mineralogical (XRD, petrography) investigation of the samples shows that the soluble fraction consists of calcite. But the presence of minor amounts of $\mathrm{MnOOH}$ cannot be ruled out. In the insoluble residue of these samples, no Mn could be detected by bulk Xray fluorescence analyses (Kuhn 1996). It is therefore concluded that analyzed Mn was mostly bound to calcite. For this rea- son, results were not calculated as percentage of the bulk rock but as percentage of the soluble fraction only. The results should equal $\mathrm{Mn} / \mathrm{Ca}$ or $\mathrm{Mn} / \mathrm{Al}$ ratios from bulk-rock measurements. The geochemical data discussed in the section on the Atlantic and the Pacific have been taken directly from the publications cited, without any additional normalization.

With regards to $\mathrm{Fe}$, the insoluble residue of carbonate samples from the Wellenberg section SB2 shows $\mathrm{Fe}_{2} \mathrm{O}_{3}$ contents ranging from 0.6 to $2.5 \mathrm{wt} \%$, and an average value is $1.8 \mathrm{wt} \%$ $(\mathrm{n}=15)$. The average $\mathrm{HCl}$-soluble $\mathrm{Fe}$ content for the same samples is $0.6 \mathrm{w} \%(\mathrm{n}=50)$, which signifies that in average, with this method and for this particular site, only about $33 \%$ of the total Fe content is captured. It is for this reason that we strictly refer to the $\mathrm{HCl}$-soluble $\mathrm{Fe}$ fraction in this contribution. The good correlation obtained between changes in $\mathrm{HCl}$ soluble $\mathrm{Mn}$ and Fe contents suggest that the $\mathrm{HCl}$-soluble $\mathrm{Fe}$ is a useful parameter and may be representative of total Fe content.

\section{A transect through the Tethys}

We chose successions outcropping in the Alpine chain and in the Carpathians for our investigation of Tethyan paleoceanography during the Valanginian (Fig. 2). As a reference section, we chose a pelagic succession that was deposited on the southern margin of the Tethys and for which a C-isotope stratigraphy has been established earlier by Lini et al. (1992). Two sections from the Helvetic nappes of central Switzerland record the evolution of the northern Tethyan carbonate ramp during the time of the $\mathrm{C}$-isotope event. These successions provide information on the link between the C-isotope excursion, the Valanginian carbonate platform-drowning episode (Föllmi et al. 1994; Weissert et al. 1998), and trace-metal concentrations. Specifically, they provide the opportunity to reconstruct tracemetal distributions along a carbonate ramp receiving clastic input from the nearby European continent. For comparison, we also investigated a northern margin sequence from the Carpathian part of the Tethys seaway and we added a Valanginian succession from the Betic Cordillera documenting the paleoceanography of the western part of the Tethys seaway.

\section{a) Southern Alps (Fig. 3)}

The studied Capriolo section is located in the Southern Alps (Northern Italy: ca. $60 \mathrm{~km}$ ENE of Milano). The Capriolo section is located paleogeographically in the Lombardian Basin. The limestones studied are part of the lower Cretaceous Maiolica Formation (Weissert 1979). The Maiolica Formation is generally described as a monotonous pelagic succession consisting of gray, well-bedded calcareous limestone with interbedded chert and rare, non-laminated black shales. The Capriolo section was documented by Lini (1994). From this section, a nannofossil and magnetostratigraphy (Channell et al. 1993), a radiolarian stratigraphy (Jud 1994) and a $\delta^{13} \mathrm{C}$ 
NAGRA Drillhole Wellenberg SB2: Helvetic Shelf

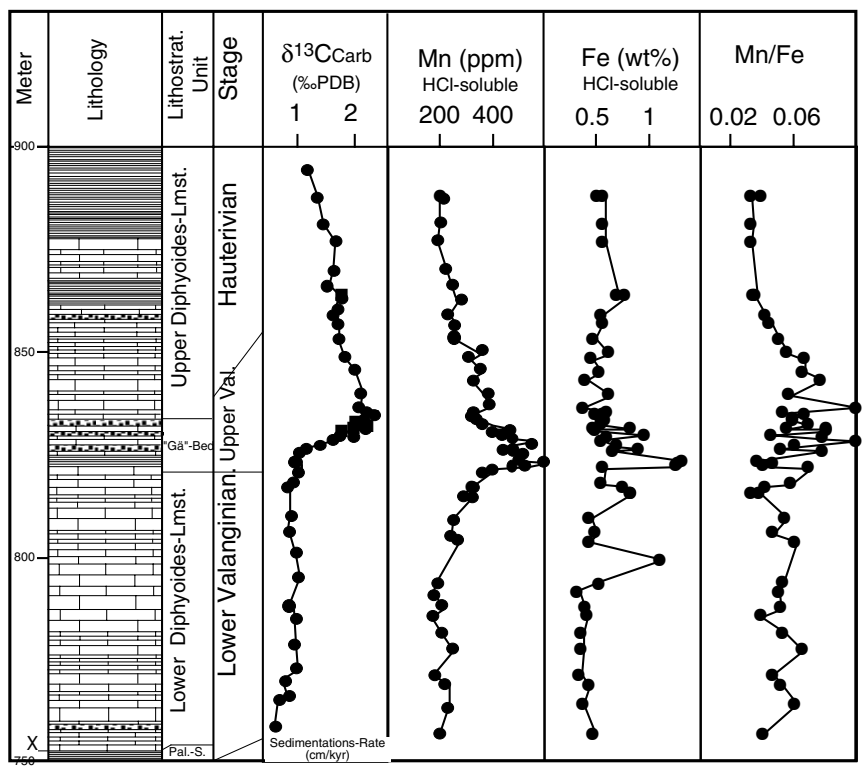

Fig. 4. NAGRA Drillhole Wellenberg SB2 from the Helvetic Alps (Central Switzerland) with lithologic succession, $\delta^{13} \mathrm{C}$-curve, contents of $\mathrm{Mn}$ and $\mathrm{Fe}$ bound in the soluble fraction and $\mathrm{Mn} / \mathrm{Fe}$-ratios calculated from these values (after Kuhn 1996). Lithologic key as in Fig. 3. Gä-B.: Gemsmättli-Bed. Pal. S.: Palfries Schiefer

chemostratigraphy (Lini et al. 1992; Lini 1994) have been established. Samples used by A. Lini for the determination of the stable isotopic composition are identical with the samples used here for the Fe and Mn analyses

\section{b) Helvetic Alps (Sections: SB2, Aeschi; Figs. 4 and 5)}

Both profiles described here are situated in the Helvetic tectonic unit, in the northern part of the Alps. The Helvetic nappes were a part of the northern Tethyan continental margin and contain neritic to pelagic sediments. The Wellenberg SB2 section is a NAGRA ("Nationale Genossenschaft für die Lagerung radioaktiver Abfälle") drill-hole, located in the Drusberg nappe in the Engelberg valley near the village Grafenort (Central Switzerland). The samples described are from an overturned limb of an anticline between 750 and $900 \mathrm{~m}$ borehole depth. The outcrop section Aeschi-Aemmital (Fig. 5) is a compilation of the sections Aeschi and Aemmital. Both sections are situated in the external part of the Helvetic zone ("Randkette") in the Entlebuch Valley ca. $4 \mathrm{~km}$ E to the village Flühli (central Switzerland). The Aeschi-Aemmital section represents a good example of the condensed facies of the inner part of the outer Helvetic shelf. The lithological succession starts with neritic to hemipelagic, cherty biomicrites and biosparites of the Lower Diphyoides Limestone Formation (early Valanginian). The overlying condensed strata contain

\section{Section Aeschi-Aemmital:} Helvetic Shelf

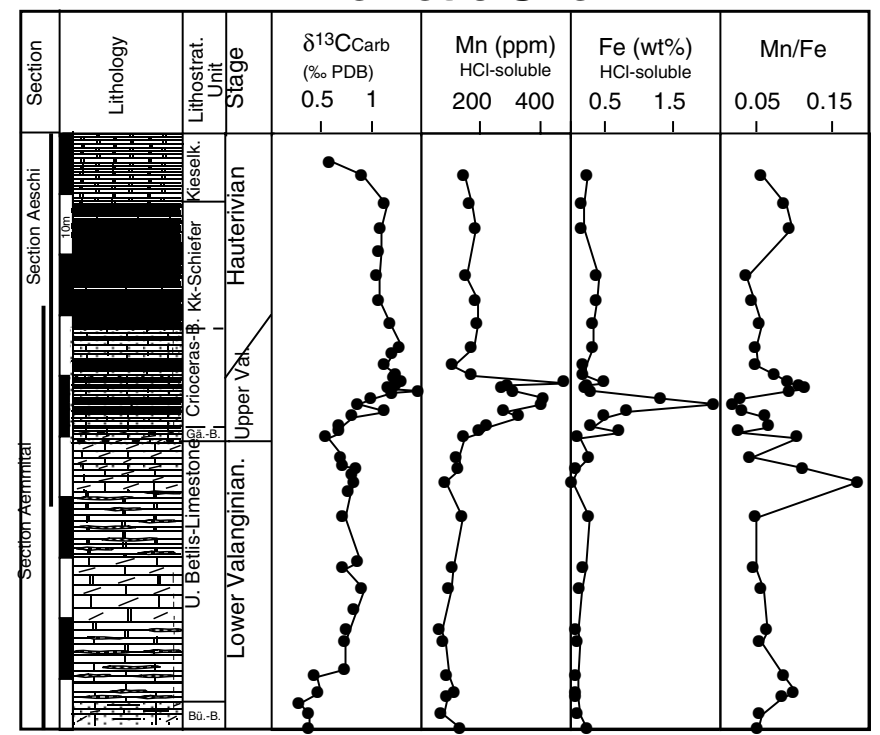

Fig. 5. Section Aeschi-Aemmital from the Helvetic Alps (central Switzerland) with lithologic succession, $\delta^{13} \mathrm{C}$ curve, contents of $\mathrm{Mn}$ and Fe bound in the dissolvable fraction and $\mathrm{Mn} / \mathrm{Fe}$-ratios calculated from these values (after Kuhn 1996). Lithologic signatures as in Fig. 3. Gä-B.: Gemsmättli-Bed, Bü-B.: Büls Bed.

coarse-grained (up to $2 \mathrm{~mm}$ ) quartz, glauconite and reworked phosphoritic clasts. The change to the hemipelagic, finegrained, micritic upper Diphyoides Limestone formation is gradual. The top of the section is made up of cherty limestones of the Kieselkalk Formation (early to late Hauterivian). The Wellenberg SB2 section contains a record which was deposited in a more distal position of the Helvetic shelf. The succession is fairly homogeneous and consists of cherty, light to dark gray limestones and marly limestones. The lower part is chertier while the upper part is marlier. Some strata contain coarse quartz grains, glauconite and small phosphoritic clasts and can therefore be lithostratigraphically correlated to the Aeschi section. $\delta^{13} \mathrm{C}$ chemostratigraphy is an appropriate stratigraphical tool for the sections in the distal part of the Helvetic zone because of the lack of macrofauna and the poor preservation of calpionellids and nannoflora (cf., Föllmi et al. 1994).

\section{c) Western Carpathians (Fig. 6)}

The Kryta valley section is located about $80 \mathrm{~km}$ south of Cracow on the western slopes of the Chocholowska Valley in the Tatra Mountains (western Carpathians, southern Poland). The Cretaceous succession of the Kryta Valley is part of the Lower Subtatric Nappes, which provides a good example of the pelagic, basinal facies of the Carpathians. The autochthonous and allochthonous nappes of the Tatra mountains formed part of 


\section{Section Kryta: Western-Carpathes}

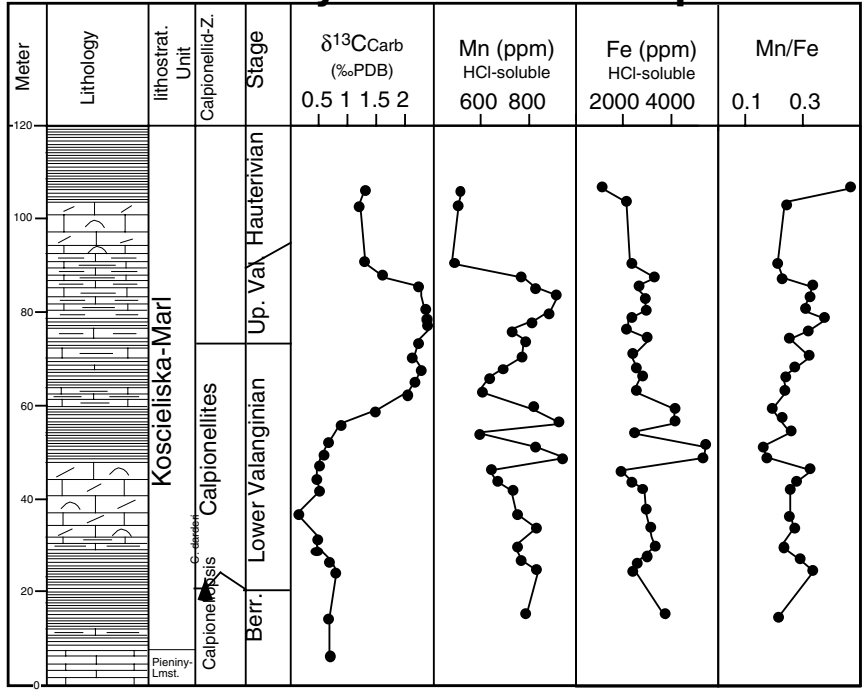

Fig. 6. Section Kryta from the western Carpathians (southern Poland) with lithologic succession, calpionellid zones (after Lefeld 1974), $\delta^{13} \mathrm{C}$-curve, contents of $\mathrm{Mn}$ and $\mathrm{Fe}$ bound in the soluble fraction and $\mathrm{Mn} / \mathrm{Fe}$-ratios calculated from these values (after Kuhn 1996). Lithologic key as in Fig. 3.

the northern margin of the Tethys ocean. The studied Kryta Valley section includes the uppermost part of the Pieniny Limestone Formation which is of Berriasian age and the Koscieliska Marl Formation which spans from the Valanginian to the Barremian. The Koscieliska Marl Formation contains dark, shaly marls and dark grey, impure limestones with intercalations of allochthonous calcarenites. Biostratigraphy of this formation has been based on ammonoids and calpionellids (Lefeld 1974).

\section{d) Betic Cordillera (Fig. 7)}

The Barranco del Garranchal section is located in the foothills of the Sierra de Quipar, near Cehegin in the Betic Cordillera (province of Murcia, Southern Spain). The Betic Cordillera is an NE-SW oriented alpine fold belt. Paleogeographically, it belonged to the continental margin of the northern side of the Tethys, with a basin and high topography similar to the southern alpine area. Tectonically, the Barranco del Garranchal section is part of the external Subbetic. The biostratigraphy of the Barranco del Garranchal section is described in Company (1987, ammonites) and Aguado (1994, nannoplankton). The section ranges from the early Valanginian (pertransiens Zone) to the base of the Hauterivian (radiatus Zone). The complete chemostratigraphy of the Barranco del Garranchon section is described in Kuhn (1996). Lower Cretaceous sediments from the External Subbetic consist of white to gray, fine-grained, marly limestones (60 to $80 \%$ carbonate) and marls. The lithological facies is similar to the Maiolica facies deposited in the southern Alps. Pyritized ammonite phragmocones are ubiqui-

\section{Section Barranco del Garranchal: Betic Cordillera}

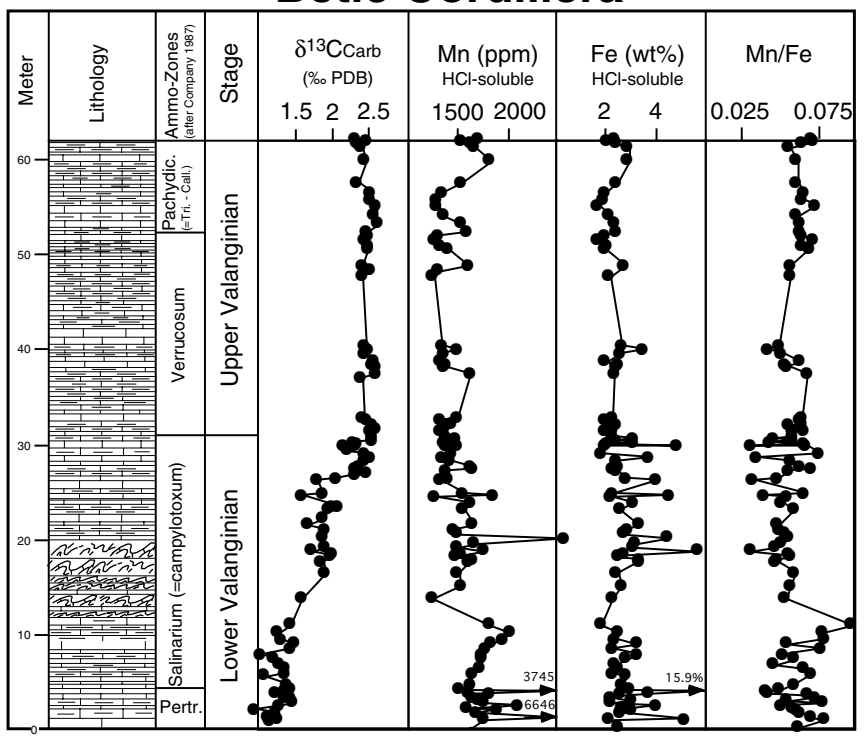

Fig. 7. Section Barranco del Garranchal (Betic Cordillera, southern Spain) with lithologic succession, ammonite zonation (after Company 1987), $\delta^{13} \mathrm{C}-$ curve, contents of $\mathrm{Mn}$ and $\mathrm{Fe}$ bound in the soluble fraction and $\mathrm{Mn} / \mathrm{Fe}-$ ratios calculated from these values (after Kuhn 1996). Lithologic key as in Fig. 3.

tous. Thick slump intervals characterize the section belonging to the lower half of the Salinarium Zone (ca. stephanophorus Zone) on a regional scale.

\section{Sample description and geochemical data}

\section{(a) Southern Alps}

Sixty-four samples from the Capriolo section were analysed for their $\mathrm{HCl}$-soluble $\mathrm{Mn}$ and $\mathrm{Fe}$ contents. $\delta^{13} \mathrm{C}$ data were taken from Lini (1994). Figure 3 shows the Capriolo section with $\delta^{13} \mathrm{C}, \mathrm{Mn}$, and Fe curves. Mn (200 - 700, max. 2500 ppm) and $\mathrm{Fe}(0.1-0.5 \mathrm{wt} \%)$ contents of the $\mathrm{HCl}$-soluble fraction are moderate and fall in the common range of pelagic carbonates. Proper Mn horizons in the form of Mn ores do not appear. The Mn content cannot be linked to any particular Mn mineral. It seems that $\mathrm{Mn}$ is fixed as a trace metal within carbonate. The background Mn content is around $400 \mathrm{ppm}$. Three parts of the succession show Mn enrichments. The highest concentrations (up to $2500 \mathrm{ppm}$ ) are recorded in a ca. 20-m-thick succession at the Berriasian/Valanginian boundary in the upper part of the angustiforata nannofossil zone. The increase in Mn concentration in this succession is linked neither to a lithological nor a paleontological (e.g., nannofossil) change. The second part that shows increased Mn contents (up to $800 \mathrm{ppm}$ ) is recorded at the boundary between the lower and upper Valanginian in the upper part of the nannofossil zone NK3 (oblongata Zone), just between the FAD (First Appearance Date) and the LAD 
(Last Appearance Date) of T. verenae. The Mn enrichment is situated below a black-shale layer and corresponds to the start of the positive $\delta^{13} \mathrm{C}$ shift and a change in the composition of calcareous nannoplankton (cf. Lini et al. 1992; Lini 1994). This part of the succession is also characterized by an increased sedimentation rate (Lini 1994), hence the Mn enrichment cannot be correlated with a drop in sediment accumulation. The third episode of Mn enrichment (max. $2000 \mathrm{ppm}$ ) is recorded during the Barremian - Aptian. This enrichment is also correlated to black shales and a positive $\delta^{13} \mathrm{C}$ shift. Fe contents of the acidsoluble fraction lie between 0.15 and $0.25 \mathrm{wt} \%$. Fe enrichments $(0.3-0.45 \mathrm{wt} \%)$ are only recorded from the part of the section with the highest $\delta^{13} \mathrm{C}$ values. The Fe maxima occur above the $\mathrm{Mn}$-enriched levels. The $\mathrm{Mn} / \mathrm{Fe}$ ratios are in the range of $0.2-1.2$. The $\mathrm{Mn} / \mathrm{Fe}$ ratios are correlated to the $\mathrm{Mn}$ contents.

\section{(b) Helvetic Alps}

Thirty-two samples from the Aeschi-Aemmital section and seventy-five samples of Drillhole SB2 were analysed for their stable isotopes ratios $(\mathrm{C}, \mathrm{O})$ and $\mathrm{HCl}$-soluble $\mathrm{Mn}$ and $\mathrm{Fe}$ content (Figs. 4 and 5 ). The $\delta^{13} \mathrm{C}$-values fluctuate between $0.5 \%$ and more than $2 \%$ and the Valanginian -Hauterivian C-isotope excursion is clearly documented in both sections studied. The base of the $\mathrm{C}$-isotope excursion coincides with a phosphorite hardground (Gemsmättli Bed; Haldimann 1977; Kuhn 1996), deposited on top of a drowned carbonate platform succession.

The Mn (150 to $600 \mathrm{ppm})$ and Fe $(0.2-2.2 \mathrm{w} \%)$ contents of the acid-soluble fraction are comparable to the values of Capriolo (Fig. 3). The Mn contents of the upper Diphyoides Limestone fluctuate around $150 \mathrm{ppm}$. Below the Diphyoides Limestone, the Mn contents reach values of up to $400 \mathrm{ppm}$ in the Aeschi-Aemmital section, and up to $650 \mathrm{ppm}$ in the Wellenberg SB2 section. Mn and Fe enrichments parallel the positive shift of $\delta^{13} \mathrm{C}$ values. In both sections the increased $\mathrm{Mn}$ and Fe contents correspond to condensed levels. The Fe content in the Aeschi-Aemmital section shows a significant increase in strata that have a high concentration of glauconite. Hence the Fe content of this section may be linked to partial dissolution of $\mathrm{Fe}$ from glauconite or related green clays. Sixteen samples of the $\mathrm{HCl}$-insoluble fraction of Wellenberg SB2 section were analysed. The Mn content is always very low in the insoluble residue and shows no major changes in Mn content within the profile. Therefore it is suggested that $\mathrm{Mn}$ is preferentially bound either to carbonate phases and/or Mn-oxides. Mn-oxides could not be identified positively in the investigated samples. The $\mathrm{Mn} / \mathrm{Fe}$ ratio is between $0.05-0.1$ in the drillhole SB2 and 0.02-0.18 in the Aeschi-Aemmital-section.

\section{(c) Carpathians}

All the samples have been made available by Dr. K. Krajewski (Polish Academy of Sciences, Warsaw, Poland). Thirty samples from the Kryta valley section were analysed for their sta- ble isotope ratios $(\mathrm{C}, \mathrm{O})$ and $\mathrm{HCl}$-soluble $\mathrm{Mn}$ and $\mathrm{Fe}$ content. Figure 6 shows the Kryta section with $\delta^{13} \mathrm{C}, \mathrm{Mn}, \mathrm{Fe}$ and $\mathrm{Mn} / \mathrm{Fe}$ curves. The $\mathrm{C}$-isotope curve shows the positive excursion with amplitude of 1.5\%. The $\mathrm{Mn}$ (500-1000 ppm) and Fe $(0.1-0.6 \mathrm{w} \%)$ concentrations are high compared to the other records presented in this study. The highest Mn (1000 ppm) and the highest Fe contents $(0.5$ to $0.6 \mathrm{w} \%)$ are recorded in the part of the section with elevated $\delta^{13} \mathrm{C}$ values. The $\mathrm{Mn} / \mathrm{Fe}$ ratios lie between 0.15 and 0.55 .

\section{(d) Betic Cordillera}

The samples from this section have been provided by A. Martin-Algarra, M. Company, and R. Aguado (all: University Granada, Spain). Eighty-seven samples from this section were analysed for their stable isotopic composition and $\mathrm{HCl}$-soluble $\mathrm{Mn}$ and $\mathrm{Fe}$ content (Fig. 7). A carbonate $\delta^{13} \mathrm{C}$ excursion is recorded from this section. It starts during the lower half of the salinarium Zone (stephanophorus Zone) and shows values near $1 \%$ up to $2.5 \%$ at the base of the verrucosum Zone. The rise of $\delta^{13} \mathrm{C}$ values is synchronous with the occurrence of slump beds. The absolute values and the amplitude of $\Delta \delta^{13} \mathrm{C}=1.5 \%$ are similar to the ones reported from other successions. $\mathrm{Mn}$ (1000-3000 ppm) and Fe (2-6w\%) contents of the acid-soluble fraction are high, compared to the other examples discussed in this paper. Mn values show a slight increase from 1500 to 2000 ppm at the base of the salinarium Zone (stephanophorus Zone). This increase is coeval to the onset of increasing $\delta^{13} \mathrm{C}$ values. Extreme values (max. $6700 \mathrm{ppm}$ ) occur at the base of the profile. The highest Fe contents (max. $6 \mathrm{w} \%$ ) are recorded in the upper part of the salinarium Zone (inonstranzewi Zone) and the base of the verrucosum Zone. The observed changes in metal contents are not linked to the lithological changes in stratigraphy. $\mathrm{Mn}$ and $\mathrm{Fe}$ are correlated and $\mathrm{Mn} / \mathrm{Fe}$ ratios lie in the range of 0.03 and 0.1 . Maximal values are found at the base of the salinarium Zone (stephanophorus Zone).

\section{The carbon-isotope record and Valanginian-Hauterivian paleoceanography}

We succeeded in reproducing an earlier-identified pronounced positive $\delta^{13} \mathrm{C}$-excursion lasting up to several million years and covering the Valanginian (Channell et al. 1993; Hennig et al. 1999, Erba et al. 2004). The measured amplitude of the excursion is $\Delta \delta^{13} \mathrm{C}=1.5 \%$, and the shape of the excursion is marked by a rapid transition to peak values and a slow return to preperturbation values that is comparable to the Aptian C-isotope event (e.g., Menegatti et al. 1998). If we correlate Valanginian-Hauterivian ammonite stratigraphy with magnetostratigraphy using C-isotope stratigraphy established at the proposed boundary stratotype "la Charce" and in the Southern Alps (Hennig et al. 1999) then the studied C-isotope excursion starts in the upper part of CM12 (Campylotoxus Zone) and it ends within CM 9 (Base of Loryi Zone). According to the correlation of Henning et al (1999) the base of the Hauterivian which 
chronostratigraphic occurence of Mn-enrichments

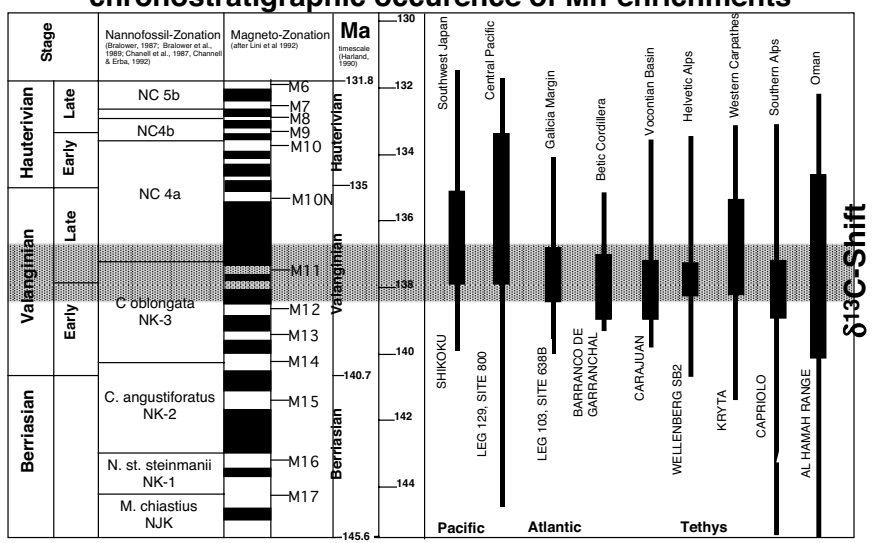

Fig. 8. Chronostratigraphic occurrence of Mn-enrichment levels in the Pacific, Atlantic and the Tethys. The grey bar marks the stratigraphic position of the positive $\delta^{13} \mathrm{C}$-shift described by Lini et al. (1992), which is interpreted as evidence of a major perturbation of the global carbon cycle.

is defined as the base of Radiatus zone correlates with CM10 and not with the base of M11n as proposed by Gradstein et al. (2004). If we assign absolute ages to the C-isotope curve we can follow Channell et al. (1995) or we can take the time scale by Gradstein et al. (2004) both based on Pacific spreading model ages. In the Channell et al. (1995) time scale the C-isotope excursion lasts from 133 my to 130 my. The Gradstein et al. (2004) time scale provides an age of about 137 my to about 133 my. In search of a possible trigger of this carbon isotope anomaly Weissert et al. (1998) recognized a close coincidence of the Parana volcanic activity and the isotope excursion. Stewart et al. (1996) dated the main episode of volcanic activity in the Paraña province (South America) as 138-131 my (Stewart et al. 1996). High basalt production rates and coupled carbon dioxide liberation could have driven atmospheric $\mathrm{CO}_{2}$ concentrations to higher values. Altered atmospheric $\mathrm{CO}_{2}$ levels would have triggered the changes in marine carbon-isotope compositions as recorded in the $\mathrm{C}$-isotope composition of the studied limestones. Available data from other C-isotope excursions indicate that the $\mathrm{C}$-isotope data record the response of the global carbon cycle and specifically of the marine carbon system to the climate perturbation triggered by excess volcanic and/or methane-derived $\mathrm{CO}_{2}$ flux (e.g., Gröcke et al. 1999).

The C-isotope data presented in this study can be used as an accurate stratigraphic tool. The data from the Helvetic carbonate ramp confirm that the Valanginian C-isotope excursion goes along with a widespread collapse of carbonate production along the northern Tethyan margin (Föllmi et al. 1994). The collapse of the Valanginian carbonate platforms was not limited to the Tethys region. $\mathrm{C}_{\text {org-isotope data from eastern north }}$ Atlantic successions indicate that platform drowning along the African continental margin also occurred at the very beginning of the Valanginian C-isotope event (Wortmann \& Weissert 2000). We propose that the observed collapse of carbonate platforms along the northern Tethyan and Atlantic margins is related to the perturbation of the global carbon cycle. Environmental stress related to $\mathrm{CO}_{2}$ induced warming, to changes in ocean chemistry and carbonate saturation, and to an increased nutrient flux from continents to oceans at a time of more humid climate may have caused the demise of carbonateproducing organisms. It seems remarkable that the observed carbonate platform collapse coincides with an earlier described growth crisis of nannoconids in the pelagic environment (Channell et al. 1993). In contrast to the large "Cismon" C-isotope event in the Aptian (Menegatti et al. 1998), only four cmthick major black shales were formed in the Tethys realm at the beginning of the Valanginian carbon isotope excursion (Lini 1994; Reboulet et al. 2003) although $\mathrm{C}_{\text {org-accumulation }}$ data from the north Atlantic suggest increased Corg burial rates at the Valanginian-Hauterivian transition (Arthur et al. 1985).

Globally intensified volcanic activity and elevated $\mathrm{CO}_{2}$ levels should have had a considerable impact on hydrological cycling, on ocean circulation, and on continental weathering and erosion patterns. In the Valanginian, a change from arid- to humid-type floras in Eurasia is documented, combined with a poleward spread of climate belts (Ziegler et al. 1987; Vakrameev 1991). Molnar (1990) and Rich et al. (1989) described the occurrence of reptiles and even amphibians from terrestrial sediments of Valanginian/Hautervian age in Australia and Antarctica. Modern amphibians and reptiles have a distribution between 0 and $60^{\circ}$ latitude and cannot withstand temperatures below $0^{\circ}$. These fossils indicate a temperate climate in polar realms. The widespread occurrence of braidedriver deposits both in low and high latitudes might also be linked to altered precipitation patterns that lead to increased runoff. Because of the development of greenhouse conditions, the resulting increase in weathering intensity should have affected the metal flux from continents to oceans.

\section{Valanginian manganese and iron enrichments: a mirror of altered metal flux and oceanography}

The most important findings from the data set presented above are: (1) $\mathrm{Mn}$ and $\mathrm{Fe}$ are enriched in Valanginian strata in all investigated sections from the Tethys. Metal enrichment coincides with the positive $\delta^{13} \mathrm{C}$-excursion (Fig. 8); (2) Mn enrichments occur both in shelf and basinal realms; (3) Fe enrichments occur mainly in terrestrial, platform, and shelf regions. Towards the basinal direction the Fe content decreases, whereas the $\mathrm{Mn} / \mathrm{Fe}$ ratios increase (approximately 0.025 to 1 ). It is evident from the discussion of the marine cycles of Fe and Mn that on a global scale the detrital Mn and Fe sources are far more important than hydrothermal ones (e.g., Fig. 1). The $\mathrm{Mn} / \mathrm{Fe}$ ratio can therefore be used as an indicator of the proximity of a certain locality to terrestrial areas, and as an indicator of the changing influence of continental metal input.

The widespread occurrence of $\mathrm{Mn}$ enrichments in the Valanginian points to an ocean-wide event, comparable to the 


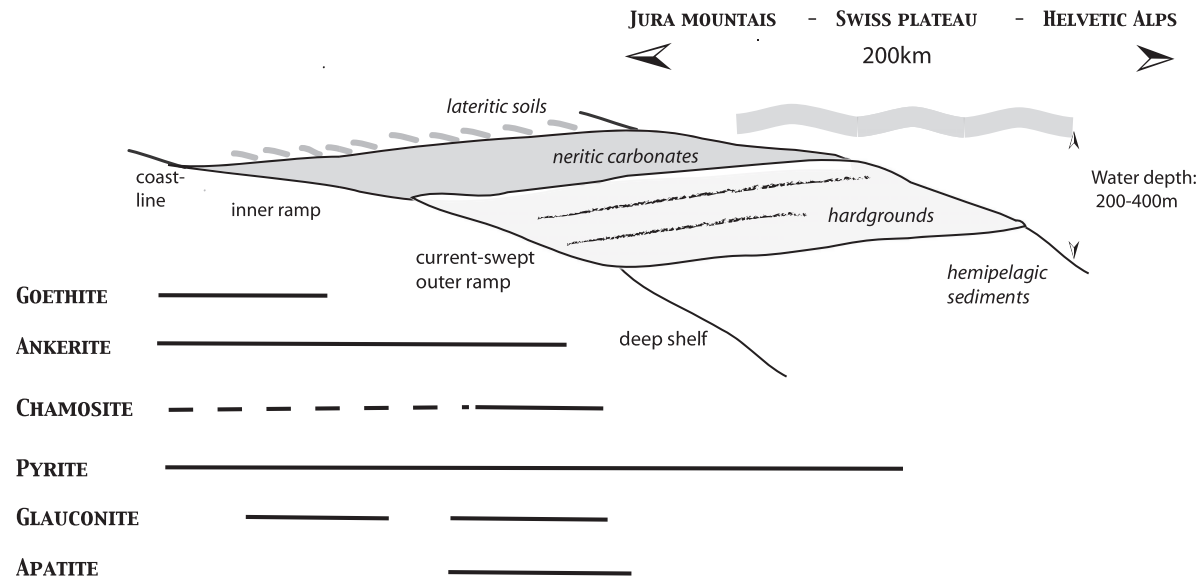

Fig. 9. The lateral distribution of Fe minerals in a transect through the northern margin of the Tethys from the Jura coast to the hemipelagic outer helvetic shelf. The Fe-content of sediments and the grain size of the Fe-bearing particles decrease in the distal direction. The mineralisation of $\mathrm{Fe}$ changes from oxidised to more reduced state in the basinal direction. These features are related to particulate $\mathrm{Fe}$ input from the terrestrial realm, followed by diagenetic remobilisation of $\mathrm{Fe}$ and reprecipitation as various authigenic minerals, according to the diagenetic environment.
Cenomanian/Turonian boundary event or to the Toarcian, where positive $\delta^{13} \mathrm{C}$ excursions coincide with peaks in Mn concentration. (e.g., Frakes \& Bolton 1984; Pratt et al. 1991; Force \& Cannon 1988; Jenkyns et al. 1991, 2002; Dickens 1994; Jarvis et al. 2001).

A common explanation for Mn enrichment is diagenetic remobilization of $\mathrm{Mn}$ in anoxic deep waters or in organic carbon-rich sediments and hence an enhanced Mn fixation in the oxygenated parts of the oceans ("bath-tub ring"- or "stratified ocean"- model; Frakes \& Bolton 1984; Force \& Cannon 1988; Jenkyns et al. 1991; Pratt et al. 1991; Dickens 1994). The Mn deficit, recorded in the basinal black-shale sediments is stated as an argument for this interpretation (e.g. Frakes \& Bolton 1984; Brumsack 1986). In this explanation, Mn-enrichment is not explained by an increased Mn flux into the ocean, but by a redistribution of $\mathrm{Mn}$ from basinal to shelfal areas. This process may explain the $\mathrm{Mn}$ enrichment in the studied pelagic sequences. If we add the Fe distribution pattern as a further source of information, we are able to show that Mn enrichment in the Valanginian sediments was caused by a combination of increased metal flux and paleoceanogaphic conditions which were favourable for metal accumulation in the sediments.

Valanginian Fe enrichments are known to be concentrated in terrestrial and shallow marine areas (Fig. 2). Fe is fixed either in Fe oolites, Fe clasts, or as limonite impregnating limestone (e.g., Jura mountains: Cayeux 1910; Guillaume 1966; Paris Basin: Taylor 1996; Estremadura in Portugal: Rey 1972; eastern Lower Saxony Basin: Michael \& Pape 1971; Iran: Robertson \& Boyle 1983; Madagascar: Besairie 1961). Accumulation of the Fe rich clays (glauconite, chamosite, chlorite) has been described from the Helvetic Alps (Haldimann 1977) and the surroundings of the Vocontian Basin (Autran 1993). Meyer (1976) described pedogenic iron enrichments and pedogenically etched quartz grains from the upper Valanginian Wealden sediments of the eastern Paris basin. Taylor (1990, 1992) described non-marine oolithic ironstones from the Upper Valanginian Wealden of South England and interpret- ed them as the result of reworking of nearby soil material. Paleosols with the development of a lateritic ferricrete-crust, pisolithic structure and pedogenically etched quartz grains have been described from the southern margin of the Subboreal basin (Harz: Valeton 1957). In addition pedogenic iron enrichment and/or continental red beds in "Valanginian" strata are described from Iran (Moussavi-Harami \& Brenner 1990), China and southeast Asia (Chen 1987), north America (Moberly 1960) and the Nubian Sandstone of North Africa and the Middle East (e.g., Abed 1982). Unfortunately the marine and terrestrial $\mathrm{Fe}$-enriched strata remain poorly dated and geochemical, petrographic and sedimentologic studies are lacking. However the Fe enrichment can be seen as a mirror of increased particulate/dissolved Fe flux from the continents into coastal environments.

Figure 9 shows a transect through the northern Tethys margin (Jura - Helvetic Alps) from coastal to hemipelagic areas. Iron occurs as various mineral phases (hematite, goethite, siderite, ankerite, chamosite, sulfides, and Fe-rich chlorite and glauconite) and grain types within this transect. Both the grain size and the Fe content diminish and the mineralisation of $\mathrm{Fe}$ changes from an oxidized to a more reduced state in a basinal direction. Detailed petrographic analyses reveal the deposition of Fe-rich continental weathering products (e.g., lateritic soil fragments, runiquartz grains, alterites) in the neritic realm during the Campylotoxus to Radiatus Zones (Kuhn 1996). Some petrographic (e.g., nuclei of Fe ooids) and geochemical (e.g. REE) characteristics of the primary material are preserved in the distally deposited Fe phases. From these findings it is concluded that the reduced Fe minerals stem from the same source as the hematitic and goethitic particles from the neritic area (Kuhn 1996). This typical distribution pattern is best explained by continental input of iron into the ocean, followed by remobilization and reprecipitation of Fe phases in relation to its diagenetic environment. Because of the ability of iron to mineralize also under reducing conditions, the major part of Fe will be buried in the vicinity of the continent. Mn, which is bound to the same particulate material arriving from 


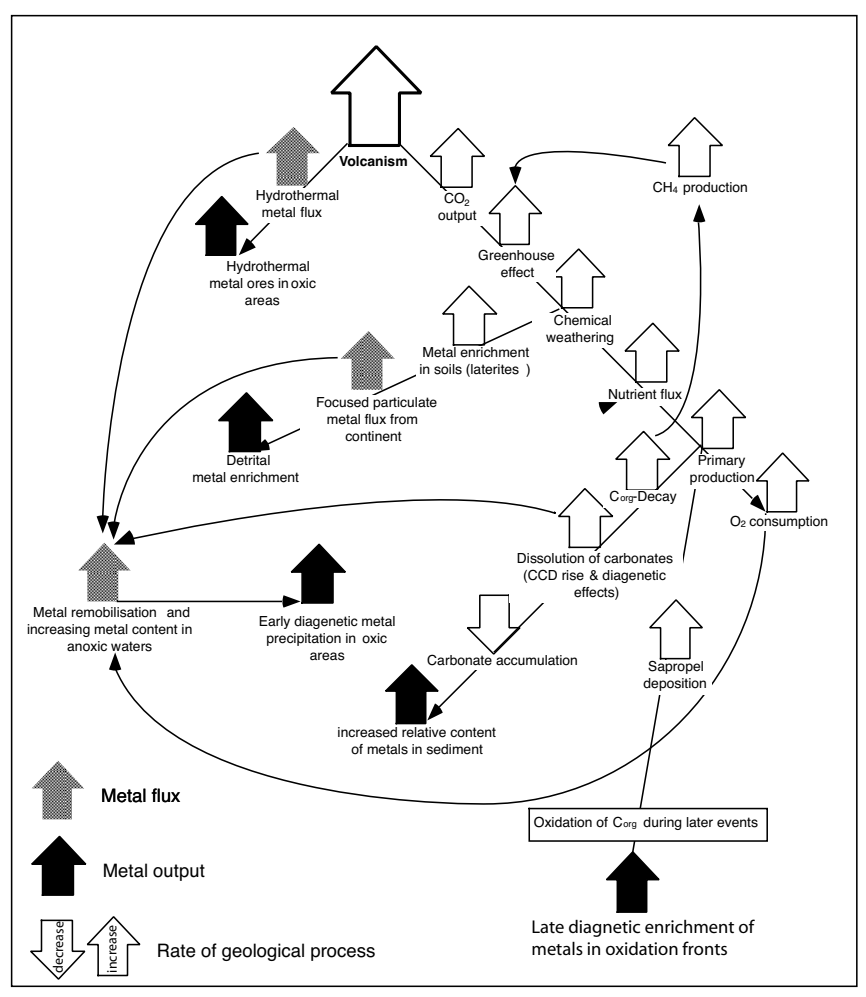

Fig. 10. A flow model to explain the polygenetic metal enrichment recorded in Valanginian sediments. We think that an increased volcanic activity is the ultimate trigger for the changes in the various oceanographic processes and element fluxes.

the continent, will be transported more distally. We think that this chromatographic type of segregation is responsible for the changing $\mathrm{Mn} / \mathrm{Fe}$ ratios in the different depositional areas (cf., Table 1).

We propose, in agreement with earlier studies (Weissert 1989; Lini et al. 1992; Föllmi et al. 1994; Kuhn 1996), that the total flux of metals from the continent increased during the Valanginian due to intensified chemical weathering, because of the start of intensified greenhouse climate conditions recorded in altered carbon cycling and the perturbation of the C-isotope curve. The widespread occurrence $\left(50^{\circ} \mathrm{S}\right.$ to $\left.50^{\circ} \mathrm{N}\right)$ of lateritic soils and their transported derivatives in the Valanginian are a strong argument for this hypothesis. The focused input of particular soil material with elevated transition metal content relative to average detritus might be an explanation for the formation of $\mathrm{Mn}$ enrichment in certain of the investigated depositional areas like the western Carpathians, the Betic Cordillera, the Helvetic shelf, or Oman, which were located not too far from continental sources.

Persoz \& Remane (1976), Sladen (1983), and Hallam (1984) reported a change from illite-dominated to kaolinite and smectite-dominated clay fractions during the Valanginian, which is another indicator of intensified chemical weathering due to increased temperature and humidity. The widespread occurrence of lateritic soils and soil fragments, buried in marine sediments signifies that iron and other transition metals are pre-concentrated in the terrestrial realm relative to other elements such as the earth-alkaline and alkaline group. The type of soils with its characteristic geochemical patterns must be interpreted as the result of strong weathering in a hot and humid climate. These tropical soils and their derivatives are spread up to $50^{\circ} \mathrm{N}$ and $50^{\circ} \mathrm{S}$. Compared to the situation in the Berriasian, there must have been an important northwards shift of the tropical climate-belt in that time (Kuhn 1996). We think, therefore that the marine Fe enrichment can be used as an indicator of weathering intensity.

\section{Conclusions}

(1) Mn and Fe are significantly enriched in Valanginian strata of the Tethys, the Pacific, and the Atlantic. The wide geographical distribution and its presence in various different depositional environments point to an ocean-wide event.

(2) The metal enrichments of the Valanginian occur in neritic, hemipelagic, and pelagic areas. They occur both in carbonate (above CCD) and non-carbonate (below CCD) settings in the deep sea. The examples from non-carbonate settings (e.g., Oman, Japan) are present as high-grade Mn ores ($80 \% \mathrm{MnO}$ ), whereas the examples from carbonate settings only show an enrichment of $\mathrm{Mn}$ as a trace element in calcite $(-0.3 \% \mathrm{MnO})$.

(3) Iron, altogether with $\mathrm{Mn}$, is enriched in the terrestrial and the shallow marine realms in low and intermediate latitudes $\left(0-50^{\circ}\right)$. The formation and erosion of lateritic soils during the Valanginian can best explain these deposits. The spread of oxisol formation indicates the evolution of a hot and humid climate at that time (Fig. 10).

(4) The metal enrichments coincide with a positive shift in the $\delta^{13} \mathrm{C}$-composition of carbonate. Comparable events are known from the early Toarcian (Jenkyns 1988; Jenkyns et al. 2002) and the Cenomanian/Turonian boundary (Frakes \& Bolton 1984; Pratt et al. 1991; Jarvis et al. 2001).

(5) The metal enrichments are explained with increased detrital $\mathrm{Mn}$ input combined with redox-related processes triggered by changes in paleoceanography during the time of the C-isotope excursion.

\section{Acknowledgements}

The authors are very grateful to Agustin Martin-Algarra and Miguel Company of Granada, Spain, to Krzyztof Krajewski of Warsaw, Poland, to Andrea Lini, of Vermont, USA, to Tjerk Peters of Bern, Switzerland, to Hans-Ruedi Pfeiffer of Lausanne, Switzerland, and to Luc Bulot of Marseille, France for the provision of sample material and data, and for analytical assistance. The sample material of the drill-hole section Wellenberg SB2 was kindly provided by the NAGRA. Hans-Peter Funk (ETH Zurich) and Thierry Adatte (University of Neuchâtel) gave important information on the sediments and stratigraphy of the Helvetic Alps and the Jura mountains. We thank Nicolas Fiet and Tom Algeo for their very careful reviews. The project was supported by the ETH Zürich and the Swiss National Science Foundation. 


\section{REFERENCES}

Abed, A. M. 1982: Depositional environments of the Early Cretaceous Kurnib (Hatira) Sandstones, north Jordan. Sedimentary Geology 31, 267-279.

Aguado, R. M. 1994: Nannofosiles del Cretacico de la Cordillera Betica (sur de Espana). Bioestratigrafia. Ph.D Thesis, Universidad de Granada, Granada (unpublished), $405 \mathrm{pp}$.

Arthur, M. A. \& DeAn, W. E. 1992: A holistic approach to cyclomania: examples from Cretaceous pelagic limestone sequences. In: EInSELE, G., Ricken, W. \& Seilacher, A. (Eds.): Cycles and Events in Stratigraphy, Springer 126-166.

Arthur, M. A., Dean, W. E. \& Schlanger, S. O. 1985: Variations in the global carbon cycle during the Cretaceous related to climate, volcanism, and changes in atmospheric $\mathrm{CO}_{2}$ : In: Sundquist, E. T. \& BroecKer, W. S. (Eds.): The Carbon Cycle and Atmospheric $\mathrm{CO}_{2}$ : Natural Variations Archean to Present: Geophysical Monograph 32, 504-529.

Autran, G. 1993: L'évolution de la marge nord-est Provencale (Arc de Castellane) du Valanginien moyen à l'Hauterivian à travers l'analyse biostratigraphique des séries de la region de Peyroules: Séries condensées, discontinuités et indices d'une tectogénese distensive. Annales du Museum d'Histoire Naturelle de Nice 10, 240 pp.

Bender, M. L., Klinkhammer, G. P. \& Spencer, D. W. 1977: Manganese in seawater and the marine manganese balance. Deep Sea Research 24, 799-812.

Berner, E. K. \& Berner, R. A. 1987: The global water cycle: Geochemistry and environment. 397 pp., Prentice-Hall, New Jersey.

Besairie, H. 1961: Les ressources minérales de Madagascar. Annales Géologiques de Madagascar 30, 1-115.

BRUMSACK, H.-J. 1986: The inorganic geochemistry of Cretaceous black shales (DSDP Leg 41) in comparison to modern upwelling sediments from the Gulf of California. In: Summerhayes, C. P. \& Shackleton, N. J. (Eds.): North Atlantic Paleoceanography. Geological Society Special Publication 21, 447-462.

Burton, J. D. \& Statham, P. J. 1988: Trace metals as tracers in the ocean. In: Charnock, H., Lovelock, J. E., Liss, P. S. \& Whitfield,M. (Eds.): Tracers in the Ocean. Proceedings of the Royal Society Discussion Meeting (21-22, May 1987), 127-146, Princeton University Press.

Calvert, S. E. \& Pedersen, T. F. 1993: Geochemistry of recent oxic and anoxic marine sediments: implications for the geological record. Marine Geology 113, 67-88.

Calvert, S. E., Bustin, R. M. \& Ingall, E. D. 1996: Influence of water column anoxia and sediment supply on the burial and preservation of organic carbon in marine shales. Geochimica et Cosmochimica Acta 60, 1577-1593.

CAYEuX, L. 1910: Les minérais de fer oolitiques primaires de France. Extrait du Bulletin de la Société géologique de France 4, 10, 531-540.

ChannelL, J. E. T., Erba, E. \& Lini, A. 1993: Magnetostratigraphic calibration of the late Valanginian isotope event in pelagic limestones from northern Italy and Switzerland. Earth and Planetary Science Letters 118, $145-166$.

Chen, P.-J. 1987: Cretaceous paleogeography in China. Palaeogeography, Palaeoclimatology, Palaeoecology 59, 50-56.

Clauser, S., Renard, M. \& Richebois, G. 1988: Variations in trace element contents and isotopic composition of lower Cretaceous carbonates from the Galicia Margin (ODP Leg 103): reconstruction of the paleochemistry of the Early Cretaceous Ocean. In: Boillot, G., Winterer, E. L., et al. (Eds.): Proceedings of the Ocean Drilling Project Scientific Results 103, 489-504.

Company, M. 1987: Los ammonitos des Valanginiense del sector oriental de las Cordilleras Beticas (SE de Espana). Ph.D Thesis, Universidad de Granada, Granada (unpublished), 294 pp.

Corbin, J.C., Person, A., Iatzoura, A., Ferré, B. \& Renard, M. 2000 : Manganese in pelagic carbonates: indication of major tectonic events during the geodynamic evolution of a passive continental margin (the Jurassic European margin of the Tethys-Ligurian Sea). Palaeogeography, Palaeoclimatology, Palaeoecology 156, 123-138.
De Rafélis, M., Emmanuel, L., Renard, M., Atrops, F. \& Jan du Chène, R. 2001: Geochemical characterization (Mn content) of third order eustatic sequences in upper Jurassic pelagic carbonates of the Vocontian Trough (SE France). Eclogae geol. Helvetiae 94, 145-152.

DiCKENS, G. R. 1994: An alternative source of manganese for Cenomanian and Turonian manganese occurrences of Israel. Israel Journal of Earth Sciences 43, 53-58.

Drever, J. I., Li, Y.-H. \& Maynard, J. B. 1988: Geochemical cycles: the continental crust and the oceans. In: Gregeor, C. B., Garrels, C. B., MacKenzie, F. T. \& Maynard, J. B. (Eds.): Chemical Cycles in the Evolution of the Earth, Wiley 17-54.

Erba, E., Bartolini, A. \& LARson, R. L. 2004: Valanginian Weissert oceanic anoxic event. Geology 32, 149-152.

Föllmi, K. B., Weissert, H., Bisping, M. \& Funk, H. P. 1994: Phosphogenesis, carbon-isotope stratigraphy, and carbonate-platform evolution along the lower Cretaceous northern Tethyan margin. Geological Society of America Bulletin 106, 729-746.

Force, E. R. \& CANnON, W. F. 1988: Depositional model for shallow marine manganese deposits around black shale basins. Economic Geology 81, 65-79.

Frakes, L. A. \& Bolton, B. R. 1984: Origin of manganese giants: sea level change and anoxic-oxic history. Geology 12, 83-86.

Frakes, L. A. \& Bolton, B. R. 1992: Effects of ocean chemistry, sea level, and climate on the formation of primary sedimentary manganese ore deposits. Economic Geology 87, 1207-1217.

Gradstein, F. M., et al 2004: A Geologic Time Scale 2004. Cambridge University Press, 589 pp.

Gröcke, D. R., Hesselbo, S. \& Jenkyns, H. C. 1999: Carbon-isotope composition of Lower Cretaceous fossil wood: ocean-atmosphere chemistry and relation to sea-level change. Geology 27, 155-158.

Guillaume, S. 1966: Le Crétacé du Jura francais: Bulletin du Bureau pour la recherche des Gisements et de Mines 15, 292 pp.

HaldimanN, P. 1977: Sedimentologische Entwicklung der Schichten an einer Zyklengrenze der helvetischen Unterkreide: Pygurus-Schichten und Gemsmättli-Schicht (Valanginian/Hauterivian) zwischen Thunersee und St. Galler Rheintal. Ph.D Thesis, Swiss Federal Institute of Technology, Zurich (unpublished), 219 pp.

Hallam, A. 1984: Continental humid and arid zones during the Jurassic and Cretaceous. Palaeogeography, Palaeoclimatology, Palaeoecology 47, 195223.

Hayes, J. M, Strauss, H. \& Kaufman, A. J. 1999: The abundance of C-13 in marine organic matter and isotopic fractionation in the global biogeochemical cycle of carbon during the past $800 \mathrm{Ma}$. Chemical Geology 161, 103-125.

Hem, J. D. 1972: Chemical factors that influence the availability of iron and manganese in aqueous systems. Geological Society of America Bulletin $83,443-450$.

Hennig, S., Weissert, H. \& Bulot, L. 1999: C-isotope stratigraphy, a calibration tool between ammonite- and magnetostratigraphy: the ValanginianHauterivian transition. Geologica Carpatica 50, 91-96.

Jarvis, I., Murphy, A. M. \& GALE, A. S. 2001: Geochemistry of pelagic and hemipelagic carbonates: criteria for identifying systems tracts and sealevel change: Journal of the Geological Society 158, 685-696.

Jenkyns, H. C. 1988: The early Toarcian (Jurassic) Anoxic Event - Stratigraphic, sedimentary and geochemical evidence. American Journal of Science 288. 101-151.

Jenkyns, H. C., Greczy, B. \& Marshall, J. D. 1991: Jurassic manganese carbonates of central Europe and the early Toarcian anoxic event. Journal of Geology 99, 137-150.

Jenkyns, H. C., Jones, C. E., Gröcke, D. R. Hesselbo, S. P. \& Parkinson, D. N. 2002: Chemostratigraphy of the Jurassic system: applications, limitations and implications for palaeoceanography. Journal of the Geological Society $159,351-378$.

JUD, R. 1994: Biochronology and systematics of Early Cretaceous radiolaria of the Western Tethys. Mémoires de Géologie (Lausanne) 19, 147pp.

KlinkHammer, G. \& Hudson, A. 1987: Dispersal patterns for hydrothermal plumes in the South Pacific using manganese as a tracer. Earth and Planetary Science Letters 79, 241-249. 
KuHN, O. 1996: Der Einfluss von Verwitterung auf die Paläozeanographie zu Beginn des Kreide-Treibhausklimas (Valanginian und Hauterivian) in der West-Tethys. Ph.D Thesis, Swiss Federal Institute of Technology, Zurich (unpublished), $380 \mathrm{pp}$.

KUMP, L. \& ARTHUR, M.A. 1999: Interpreting carbon-isotope excursions: carbonates and organic matter. Chemical Geology 161, 181-198.

Landing, W. M. \& Bruland, K. W. 1980: Manganese in the North Pacific. Earth and Planetary Science Letters 49, 45-56.

LEFELD, J. 1974: Middle-Upper Jurassic and Lower Cretaceous biostratigraphy and sedimentology of the Sub-Tatric succession in the Tatra Mountains (Western Carpathians). Acta Geologica Polonica 24, 277-364.

LiNI, A. 1994: Early Cretaceous carbon isotope stratigraphy of the Majolica Formation, Southern Alps (Northern Italy and Southern Switzerland): stratigraphic and paleoenvironmental significance. Ph.D Thesis, Swiss Federal Institute of Technology, Zurich (unpublished), $259 \mathrm{pp}$.

Lini, A., Weissert, H. \& Erba, E. 1992: The Valanginian carbon isotope event: a first episode of greenhouse climate conditions during the Cretaceous. Terra Nova 4, 374-384.

LisitZIN, A.P. 1996: Oceanic sedimentation: Lithologie and geochemistry. American Geophysicial Union, 400 pp.

Martin, J. H, \& Knauer, G. A. 1982: Managnese cycling in northeast Pacific equatorial waters. J. of Marine Research 40, 1213-1225.

Martin, J. H. \& Knauer, G. A. 1983: VERTEX: Manganese transport with $\mathrm{CaCO}_{3}$. Deep Sea Research 30, 411-425.

Menegatti, A. P., Weissert, H., Brown, R., Tyson, R. V., Farrimond, P., Strasser, A. \& CARON, M. 1998: High resolution $\delta^{13} \mathrm{C}$-stratigraphy through the early Aptian "Livello Selli Equivalent" of the Alpine Tethys. Paleoceanography 13, 530-545.

Meyer, R. 1976: Continental sedimentation, soil genesis and marine transgressions in the basal beds of the Cretaceous in the east of the Paris Basin. Sedimentology 23, 235-253.

MikHailov, B. M. et al. 1973: Explanations to the Map of bauxite deposits of the USSR, Scale 1:5000000: Ministerstvo Geologica SSSR and VSGEGEI Leningrad 1-58.

Michael, E. \& PAPE, H. 1971: Eine bemerkenswerte Bio- und Lithofazies an der Basis des Unter-Hauterivium Nordwest-Deutschlands. Mitteilungen aus dem geologischen Institut der Universität Hannover 10, 43-108.

Moberly, R. 1960: Morrison, Cloverley, and Sykes Mountain Formations, northern Bighorn Basin Wyoming and Montana. Geological Society of America Bulletin 71, 1137-1176.

MolnaR, R. E. 1990: Terrestrial tetrapods in cretaceous Antarctica, In: Crame J. A. (Ed.): Origins and Evolution of the Antarctic Biota. Geological Society Special Publication 47, 131-140.

Moussavi-Harami, R. \& BRenNeR, R. L. 1990: Lower Cretaceous (Neocomian) fluvial deposits in eastern Kopet-Dagh Basin, northeastern Iran. Cretaceous Research 11, 163-174.

Persoz, F. \& Remane, J. 1976: Minéralogie et géochemie des formations à la limite Jurassique-Cretace dans le Jura et le basin vocontienne. Eclogae geol. Helvetiae 69, 1-38.

Pomerol, B. 1983: Geochemistry of the late Cenomanian - early Turonian chalks of the Paris basin: manganese and carbon isotopes in carbonates as paleoceanographic indicators. Cretaceous Research 4, 85-93.

Pratt, L. M., Force, E. R. \& Pomerol,B. 1991: Coupled manganese and carbon isotopic events in marine carbonates at the Cenomanian-Turonian boundary. Journal of Sedimentary Petrology 61, 370-383.

Reboulet, S., Mattioli, E., Pittet, B., Baudin, F., Olivero, D. \& Proux, D. 2003: Ammonoid and nannoplankton abundance in Valanginian (early Cretaceous) limestone-marl successions from the southeast France Basin carbonate dilution or productivity? Palaeogeography, Palaeoclimatology, Palaeoecology 201,113-139.

REY, J. 1972: Recherches géologiques sur le Crétacé Inferieur de l'Estremadura (Portugal). Servicios geologicos Portugal, Memoires, 162 pp.

Rich, T. H., Rich, P. V., Wagstaff, B., McEwen-Mason, J., Douthitt, C. B. \& GREGORY, R. T. 1989: Early Cretaceous biota from the northern side of the Australo-Antarctic rift valley. In: CrAmE J. A. (Ed.): Origins and Evolution of the Antarctic Biota. Geological Society Special Publication 47, $121-130$.
Robertson, A. H. F. \& Boyle, J. F. 1983: Tectonic setting and origin of metalliferous sediments in the Mesozoic Tethys ocean. In: RonA, P. A., Bostrom, K., Laubier, L. \& Smith K. L. JR. (Eds.): Hydrothermal Processes of Seafloor Spreading Centers, Plenum Press, 595-663.

Schlanger, S. O., Arthur, M. A., Jenkyns, H. C. \& Scholle, P. A. 1987: The Cenomanian-Turonian anoxic event, 1. stratigraphy and and distribution of organic carbon rich beds and the marine $\delta^{13} \mathrm{C}$-excursions. In: Brooks, J. \& FleEt, A. J. (Eds.): Marine Petroleum Source Rocks. Geological Society Special Publication 26, 371-399.

SEIBOLD, E. \& BERgER, W. H. 1993: The sea floor - an introduction to marine geology. Springer Verlag, 356 pp.

Sladen,C. P. 1983: Trends in early Cretaceous clay mineralogy in N.W. Europe. Zittelania 10, 349-357.

Stewart, K., Turner, S., Kelley, S., Hawkesworth, C., Kirstein, L. \& Mantovani, M. 1996: 3-D, ${ }^{40} \mathrm{Ar}-{ }^{39} \mathrm{Ar}$ geochronology in the Parana continental flood basalt province. Earth and Planetary Science Letters 143, 95-109.

TAYLOR, K. G. 1990: Berthierine from the non-marine Wealden (Early Cretaceous) sediments of South-East England. Clay Minerals 25, 391-399.

TAYLOR, K. G. 1992: Non-marine oolithic ironstones in the lower Cretaceous Wealden sediments of southeast England. Geological Magazine 129, 349-358.

TAYLOR, K. G. 1996: Early Cretaceous iron ooids in the Paris Basin, pedogenic versus marine origin and their paleoclimatic significance. Cretaceous Research 17/1, 109-118.

VAKhrameev, V. A. 1991: Jurassic and Cretaceous floras and climates of the Earth. Cambridge University Press, 318 pp.

VALETON, I. 1957: Lateritische Verwitterungsboden zur Zeit der jungkimmerischen Gebirgsbildung im nördlichen Harzvorland. Geologisches Jahrbuch 73, 149-164.

Van Houten, F. B. \& Arthur, M. A. 1989: Temporal patterns among Phanerozoic oolitic ironstones and ocean anoxia. In: YounG, T. P. \& TAYLOR, W. E. G. (Eds.): Phanerozoic Ironstones. Geological Society Special Publication 46, 33-50.

Weissert, H. 1979: Die Paläozeanographie der südwestlichen Tethys in der Unterkreide: Mitteilungen des geologischen Institutes der ETH und Uni Zürich, Neue Folge 226, 174 pp.

WeIsSERT, H. 1989: C-Isotope stratigraphy, a monitor of paleoenvironmental change: a case study from the Early Cretaceous. Surveys in Geophysics 10, $1-61$.

Weissert, H., LinI, A., Föllmi, K. B. \& KuHN, O. 1998: Correlation of Early Cretaceous carbon isotope stratigraphy and platform drowning events: a possible link. Palaeogeography, Palaeoclimatology, Palaeoecology 137, 189-203.

Wolery, T. J. \& SLEEP, N. H. 1988: Interactions of geochemical cycles with the mantle. In: Gregor, C. B., Garrels, C. B., MacKenzie, F. T. \& Maynard, J. B. (Eds.): Chemical Cycles in the Evolution of the Earth, Wiley, 77-104.

Wortmann, U. \& Weissert, H. 2000: Tying platform drowning to perturbations of the global carbon cycle with a $\delta^{13} \mathrm{C}_{\text {org }}$-curve from the Valanginian of DSDP Site 416. Terra Nova 12, 289-294.

Ziegler, A. M, Raymond, A. L., Gierlowski, T. C., Horrell, M. A., RowELL, D. B. \& LOTTES, A. L. 1987: Coal, climate and terrestrial productivity: the Present and early Cretaceous compared. In: Scott, A. C. (Ed.): Coal and Coal Bearing Strata: Recent Advances. Geological Society Special Publication 32, 25-50.

Manuscript received November 22, 2004

Revision accepted November 25, 2005 